\title{
Treatment Effects of Onion (Allium cepa) and Ginger (Zingiber officinale) on Sexual Behavior of Rat after Inducing an Antiepileptic Drug (lamotrigine)
}

\author{
Arash Khaki ${ }^{1}$, Alireza Farnam², Arash Davatgar Badie ${ }^{1}$, Hussein Nikniaz ${ }^{1}$ \\ ${ }^{1}$ Women's Reproductive Health Research Center, Tabriz University of Medical Sciences, Tabriz, Iran \\ ${ }^{2}$ Department Clinical Psychiatry Research Center, Tabriz University of Medical Sciences, Tabriz, Iran
}

\begin{abstract}
Objective: The aim of the present study was to evaluate the beneficial degree of sexual behavior in male rats after inducement of onion and ginger in lamotrigine receiving groups.

Material and Methods: Wistar rats $(n=70)($ male $=35$, female=35) were allocated so that males were divided into seven groups: control ( $n=5)$ and test groups ( $n=35)$. Control group used normal Saline ( $3 \mathrm{cc}$ for each rat). Lamotrigine group were given Lamotrigine $(10 \mathrm{mg} / \mathrm{kg})$. Onion group used onion fresh juice (3 cc for each rat/daily). Ginger group was fed on ginger powder ( $100 \mathrm{mg} / \mathrm{kg} /$ daily). Onion \& Lamotrigine group used both onion juice ( $3 \mathrm{cc}$ fresh onion juice for each rat/day) and Lamotrigine (10 mg/kg). Ginger \& Lamotrigine group used both ginger powder (100 mg/kg/day) and Lamotrigine (10 mg/kg/day). Onion, ginger \& Lamortigine group jointly used ginger powder (100 mg/kg/day) and onion juice (3 cc juice for each rat) and Lamotrigine $(10 \mathrm{mg} / \mathrm{kg} / \mathrm{day})$. All groups were given treatments orally. For sexual behaviors, Estradiolbenzoate (50 microgram) and 6 hours before test (500 microgram) progesterone was injected to the female rats subcutaneously. Then rats were viewed for erection, ejaculation and cup.
\end{abstract}

Results: There was maximum Serum total testosterone level in the onion group, there was maximum malondialdehyde (MDA) in the Lamotrigine group and there was maximum total antioxidant capacity in both the onion group and ginger group $(p<0.05)$.

Conclusion: Results revealed that administration of ( $100 \mathrm{mg} / \mathrm{kg} /$ day) of ginger powder, and freshly prepared onion juice ( $3 \mathrm{cc}$ for each rat), significantly lowered the adverse effects of lamotrigine, and can have beneficial effects on sexual behavior in male rat.

Key Words: Allium cepa, antiepileptic, lamotrigine, sexual behavior, Zingiber officinale

Received: 29.12.2011

Accepted: 05.06.2012

\section{Introduction}

One of the most important issues that influence the individual and social life of humans is sexual intentions. Sexual behavior is one of the major health issues in life $(1,2)$. Several conditions can interfere with sexual behavior and many factors such as drug treatment, chemotherapy, toxins, air pollution, and insufficient vitamin intake may have harmful effects on sexual behavior (3).

Nowadays ginger rhizome (Zingiber officinale R., family: Zingiberaceae), is used worldwide as a spice. Both antioxidative and androgenic activities of $Z$. officinale were reported in animal models $(4,5)$. The onion (Allium cepa) has long been used in traditional medicine, is one of the important Allium species commonly used in our daily diet, and has recently been the source of much interest because of its antithrombotic, hypolipidaemic, hypotensive, diaphoretic, antibiotic, anti-diabetic, anti atherogenic, and anticancer medicinal properties $(6,7)$. The biological action of Allium products is ascribed to organosulfur and phenolic compounds. It has been found that administration of onion products to diabetic rats significantly reduced hyperglycemia (8).

Furthermore, the role of nutritional factors in reproduction and subfertility is important. Researches have shown that onion contains exogenous and endogenous antioxidants such as selenium, glutathione, vitamins $A, B$, and $C$, and flavonoids such as quercetin and isorhamnetin (9). These antioxidants protect DNA and other important molecules from oxidation and damage, which would otherwise induce apoptosis, and could improve sperm health parameters, increasing the rate of fertility in men $(10,11)$. All major active ingredients of $Z$. officinale, such as zingerone, gingerdiol, zingibrene, gingerols and shogaols, have antioxidant activity (12).

Therefore, the role of nutritional and biochemical factors in reproduction and sub-fertility treatment is very important. As mentioned, among the destructive elements, the role of 
psychological issues is more important. Tension, depression, and bad memories such as environments and special color, are among the harmful elements in sexual functions that psychotherapy and consulting causes satisfactory results in sexual behaviors (13). Cultural-educational issues and sexual deviations have destructive influences that have psychological origins (14). Psychological and neurobiological elements are influential in reducing the sexual drive. Moreover, some hormonal disorders such as increase in Prolactin in females, reduction of estrogen in females and testosterone in males have negative influences on sexual behavior and on the contrary; there are elements that can have positive influences on sexual behavior and function such as improving the function of endocrine and hormone levels in the body, which is achieved through preventing the reduction of estrogen and progesterone in females, preventing the reduction of Dopamine in males and females, preventing the reduction of testosterone in males so that all these changes in hormone densities could have great influences on sexual behaviors (15).

In addition, some drugs and materials indirectly have psychological affects; Opioid drugs (such as Methadone) and using Heroines can have negative influence on sexual function (16). Different non-medical self-treatments (such as using narcotics or ecstasy) have retarding influences on sexuality (17). Using alcohol is one of the destructive elements on sexuality (18). Diets such as fruits and vegetables, which are full of vitamins, are very useful (19).

Lamotrigine is an anti-convulsant drug for controlling the glutamate that is used to treat the first convulsions and inclusive tonic-clonic convulsions and depressive and bipolar disorders. Men with epilepsy have reduced fertility, and antiepileptic drugs may affect semen quality. Disturbances of reproductive endocrine hormones are more often found in men with epilepsy than in the general population. There is an ongoing debate whether this can be attributed to chronic use of antiepileptic drugs or to the epilepsy itself (2).

The present study was planned to assess the ability of onion and ginger on the sexual behavior of rats after lamotrigine to promote sperm parameters and modulate testosterone concentration, spermatogenesis and oxidative stress. The results obtained will provide further insights into appropriate treatment of male patients by improving sexual behavior.

\section{Material and Methods}

\section{Plant material}

\section{Preparation of onion juice}

The underground yellowish-white bulbs of Allium cepa (onion) were collected in August 2007 from Ilkhchi-Tabriz in the province of East Azerbaijan-Iran. The skin was removed and fresh juice of onions was prepared using a fruit juice extracting machine before the experiments (2).

\section{Analysis of onion juice}

The onion juice was tested for the determination of flavonoids using the Shinoda test (20). Qualitative thin-layer chromatography (TLC) was employed for determination of querce- tin as a main flavonoid in onion. For TLC, $10 \mathrm{~mL}$ of fresh onion juice was dried in a vacuum and the resulting residue dissolved in $1 \mathrm{~mL}$ of methanol. $20 \mathrm{~mL}$ of methanolic solution was spotted on a silica gel plate $(10 \times 20 \mathrm{~cm}$, silica gel 60 GF254, Merck, Darmstadt, Germany) with a solvent system of EtOAc/ $\mathrm{MeOH}$ (80:20). Quercetin, Sigma chemical Co. (St. Louis, MO, USA) was used as a control. After developing and drying, the TLC plate was sprayed with a $2 \% \mathrm{AlCl} 3$ solution in methanol. Quercetin in the onion samples appeared as a yellow spot at $\mathrm{RF}=0.6$ Separation of quercetin was performed with further purification by preparative TLC on silica gel and quantitative determination of quercetin carried out on a Model 2100 Spectrophotometer (Shimadzu, Japan) in $370 \mathrm{~nm}$ by comparing to a pure quercetin standard curve. The amount of quercetin in fresh onion was (12 mg/100 g).

\section{Experimental animals}

Adult Wistar albino rats $(n=70)$, which were bought from the Pasteur Institute in Iran, were used in the research. The rats were 8 weeks old and their weight was mostly ( $220 \pm 10 \mathrm{gr})$. During the research, these animals were kept 12 hours in darkness and 12 hours in light condition (9 a.m to 9 p.m). The temperature was $\left(23.3-25.9^{\circ} \mathrm{C}\right)$ and the humidity in the room was (55-60\%). All rats were fed a standard diet and water. Everyday a fresh onion was turned to juice using a juice machine (11). Male rats were divided randomly into 7 groups of 5 rats. The first group used normal saline (3 cc for each rat/day) (control group) orally. The second group were given Lamotrigine (10 mg/kg/day) for 4 weeks (Lamotrigine group) orally. The third group used onion juice (3 cc for each rat/day) (onion group) orally. Moreover, the fourth group was fed with ginger powder (100 mg/kg/day) (ginger group) orally, the fifth group used both onion juice (3 cc fresh onion juice for each rat/day) and lamotrigine $(10 \mathrm{mg} / \mathrm{kg} /$ day) (onion and Lamotrigine group) orally. The sixth group used both ginger powder (100 mg/kg/day) and Lamotrigine $(10 \mathrm{mg} /$ $\mathrm{kg}$ ) (ginger and lamotrigine group) orally. The seventh group jointly used ginger powder ( $100 \mathrm{mg} / \mathrm{kg} /$ day) and onion juice (3 cc juice for each rat/day) and lamotrigine (10 mg/kg/day) (onion, ginger and lamortigine group) orally. 48 hours before studying the sexual behaviors of the rats, Estradiol benzoate (50 microgram) were injected hypodermically for female rats and 6 hours before the test, progesterone ( 500 microgram) was injected hypodermically and after the $4^{\text {th }}$ week, after analyzing the sexual behaviors of the rats, bleeding was carried out through the eyes (2).

\section{Surgical procedure}

After the $4^{\text {th }}$ week, pentobarbital $(40 \mathrm{mg} / \mathrm{kg}$ ) was used for tranquilizing by injection into the peritoneum and then the peritoneum was opened by an incision the width of the abdomen. Then, testes were taken out for study groups and were weighed. At the end of the study, all the animals were killed after 4 weeks according to the law of protecting the animals (21). The animals were killed by CO2 gas in two hours (9-11 a.m). Blood samples were obtained. Blood samples were centrifuged at $4^{\circ} \mathrm{C}$ for $10 \mathrm{~min}$ at $250 \mathrm{Xg}$ and the serum obtained was stored at $-20^{\circ} \mathrm{C}$ until assayed. 


\section{Weighing the tissue of the testes}

In order to weigh the testes, a A\&D brand digital balance was used which was made in Korea.

\section{Serum total testosterone hormone}

Serum concentration of total testosterone from male rats was measured by using a double antibody RIA kit from Immunotech Beckman Coulter, USA. The sensitivities of hormone detected per assay tube were $0.025 \mathrm{ng} / \mathrm{mL}$ (22).

\section{Preparing the samples of testis tissue for studying under the light microscope}

The samples were immersed in 10 percent buffer formalin and stabilized and after preparing the microscopic sections by a thickness of $5 \mu$, were stained by $H \& E$ (16). Then in order to prepare pictures the (ASA) 400 Kodak Ultra film and Light microscope (model Olympus $/ 3 \mathrm{H}-\mathrm{Z}$ made by Japan) were used.

\section{The study method of sexuality}

Forty-eight hours before studying the sexual behaviors, Estradiolbenzoate (50 microgram) and 6 hours before the test (500 microgram) progesterone was injected to the female rats subcutaneously. Then rats were kept in glass cages in pairs and they were filmed by cameras for 1 hour in darkness. This information (erection, ejaculation and cup) was recorded (23).

Total antioxidant capacity (TAC) and malondialdehyde (MDA) concentration measurement in serum

A TAC detecting kit was obtained from Nanjing Jiancheng Bioengineering Institute-China. According to this method, the antioxidant defense system, which consists of enzymatic and non-enzymatic antioxidants, is able to reduce $(\mathrm{Fe} 3+)$ to $(\mathrm{Fe} 2+)$. TAC was measured by the reaction of phenanthroline and (Fe2+) using a spectrophotometer at $520 \mathrm{~nm}$. At $37^{\circ} \mathrm{C}$, a TAC unit is defined as the amount of antioxidants required to make absorbance increase 0.01 in $1 \mathrm{~mL}$ of serum (24).

Free radical damage was determined by specifically measuring MDA. MDA was formed as an end product of lipid peroxidation which was treated with thiobarbituric acid to generate a colored product that was measured at $532 \mathrm{~nm}$ ((MDA) detecting kit from Nanjing Jiancheng Bioengineering Institute-China) (2).

\section{Statistical analyses}

Statistical comparisons were made using the ANOVA test for comparison of data in the control group and the experi- mental groups. The results were expressed as mean ( \pm SEM) (standard error of means). Significant difference is written in parentheses.

\section{Results}

\section{Weight of individual male testis}

The obtained results in this study are illustrated in Table 1, There was no significant difference in testes weights between the groups. The results of analyzing the changes in weighing the testes of the control group was $(1.4 \pm 0.8 \mathrm{gr})$, in the Lamotrigine group it was $(1.25 \pm 0.1 \mathrm{gr})$, in the onion group it was equal to $(1.41 \pm 0.5 \mathrm{gr})$, in the ginger group it was $(1.41 \pm 0.5$ $\mathrm{gr})$, in the group where the rats were fed with Lamotrigine and onion it was $(1.52 \pm 0.5 \mathrm{gr})$, and in the group where rats were fed with Lamotrigine and ginger the result was $(1.33 \pm 0.5 \mathrm{gr})$, and finally in the group fed with onion, ginger and Lamotrigine it was $(1.42 \pm 0.5 \mathrm{gr})$.

\section{Results of serum total testosterone}

On administration of (100 mg/kg/day) ginger for 4 consecutive weeks, serum total testosterone level increased significantly $(p<0.05)$ in animals received $(100 \mathrm{mg} / \mathrm{kg} /$ day $)$ ginger in comparison to the control group and administration of (3 cc juice for each rat) fresh onion juice daily for 4 consecutive weeks significantly increased serum total testosterone. The results of analyzing the testosterone changes in control groups equal to $(1.7 \pm 0.05 \mathrm{ngr} / \mathrm{mL})$. In the Lamotrigine group it was $(1.13 \pm 0.06 \mathrm{ngr} / \mathrm{mL})$, in the onion group there was highest level, $(2.3 \pm 0.05 \mathrm{ngr} / \mathrm{mL})$. In the ginger group it was $(2.1 \pm 0.01$ $\mathrm{ngr} / \mathrm{mL}$ ) and in the groups of rats that used both Lamotrigine and ginger was $(1.6 \pm 0.05 \mathrm{ngr} / \mathrm{mL})$. In the group that used both Lamotrigine and onion it was $(1.63 \pm 0.05 \mathrm{ngr} / \mathrm{mL})$, and in the group where rats were fed with onion, ginger and Lamotrigine it was $(2 \pm 0.05 \mathrm{ngr} / \mathrm{mL})(\mathrm{p}<0.05)$ (Table 1).

\section{Results of total antioxidant capacity and}

malondialdehyde concentration measurement in serum

The mean concentration of MDA level was significantly $(p<0.05)$ lower in the onion group $(3.2 \pm 0.05)$ and ginger group $(3.3 \pm 0.05)$ in comparison to the control group $(4 \pm 0.05)$

In the onion and lamotrigine group the level of the MDA was (4.66 \pm 0.05$)$. In the ginger and lamotrigine group

Table 1. Means of serum TAC, MDA, Testosterone levels and Testis weights in studied groups and their results

\begin{tabular}{|c|c|c|c|c|c|c|c|}
\hline Variables & $\begin{array}{l}\text { Control } \\
\text { group }\end{array}$ & $\begin{array}{l}\text { Lamotrigine } \\
\text { group }\end{array}$ & $\begin{array}{l}\text { Onion } \\
\text { group }\end{array}$ & $\begin{array}{l}\text { Ginger } \\
\text { group }\end{array}$ & $\begin{array}{c}\text { Onion \& } \\
\text { Lamotrigine } \\
\text { group }\end{array}$ & $\begin{array}{c}\text { Ginger \& } \\
\text { Lamotrigine } \\
\text { group }\end{array}$ & $\begin{array}{c}\text { Onion, } \\
\text { ginger \& } \\
\text { Lamotrigine } \\
\text { group }\end{array}$ \\
\hline Testosterone (ngr/mL) & $1.7 \pm 0.05$ & $1.13 \pm 0.06$ & $2.3 \pm 0.05^{\star}$ & $2.1 \pm 0.01^{\star}$ & $1.63 \pm 0.05$ & $1.6 \pm 0.05$ & $2 \pm 0.05^{\star}$ \\
\hline T.A.C (mmol/mL) & $0.53 \pm 0.66$ & $0.41 \pm 0.05$ & $0.64 \pm 0.05^{\star}$ & $0.64 \pm 0.05^{\star}$ & $0.5 \pm 0.61$ & $0.48 \pm 0.05$ & $0.51 \pm 0.05$ \\
\hline M.D.A (mmol/mL) & $4 \pm 0.05$ & $6 \pm 0.05^{\star}$ & $3.2 \pm 0.05^{\star}$ & $3.3 \pm 0.05^{\star}$ & $4.66 \pm 0.05$ & $5.01 \pm 0.05$ & $4.44 \pm 0.05$ \\
\hline Testes W. (gr) & $1.4 \pm 0.8$ & $1.25 \pm 0.1$ & $1.41 \pm 0.5$ & $1.41 \pm 0.5$ & $1.52 \pm 0.5$ & $1.33 \pm 0.5$ & $1.42 \pm 0.5$ \\
\hline
\end{tabular}


$(5.01 \pm 0.05)$ and in the ginger, onion, lamotrigine group $(4.44 \pm 0.05)$ (Table 1$)$. Total antioxidant capacity (TAC) was significantly higher $(p<0.05)$ in the onion group $(0.64 \pm 0.05)$ and ginger group $(0.64 \pm 0.05)$ as compared with control group $(0.53 \pm 0.66)$. In the onion and lamotrigine group TAC was $(0.5 \pm 0.61)$. In the ginger and lamotrigine group it was $(0.48 \pm 0.05)$ and in the onion, ginger, lamotrigine group it was $(0.51 \pm 0.05)$ (Table 1$)$.

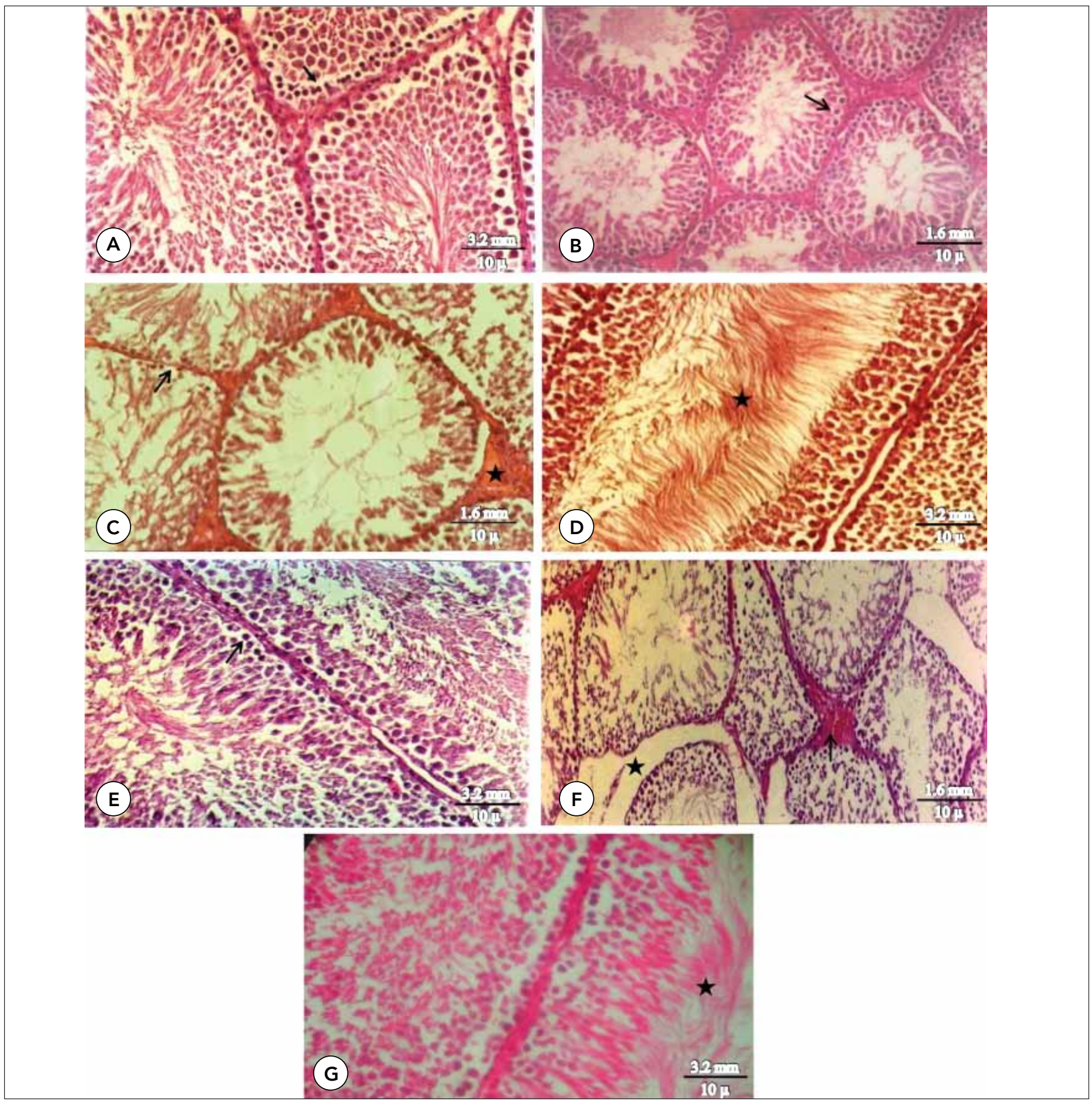

Figure 1. A) Seminiferous tubule showed all germinal cells, (arrow) in the onion group (H\&E, x320), B) Regular seminiferous tubule (arrow) with normal testicular parenchyma tissue morphology in the control group (H\&E, $\times 160)$. C) Damage of germinal epithelium (arrow) with destruction of testicular parenchyma tissue and fibrosis in inter tubular space (star) morphology in the lamotrigine group (H\&E, x160), D) Normal germinal epithelium, sperm presence in lumen (star) in the ginger group (H\&E, x320), E) Seminiferous tubule, with germinal epithelium (arrow) in the ginger\&lamotrigine group (H\&E, $x 320$ ). F) Congestion (arrow) with edema in intertubular space (star) in the onion\&lamotrigine group (H\&E, $x 160)$ ). $G$ ) Recovery of seminiferous tubule, sperm presence in lumen of seminiferous tubule (star) in the onion\&ginger\&lamotrigine group (H\&E, x320) 


\section{Results of light microscopic study}

Studying the groups that received onion ( $3 \mathrm{cc}$ fresh onion juice for each rat) it was observed that sperm counts are high in the lumen tubule of seminiferous and they are present in all sexual cells in comparison with control groups and it was concluded that onion has a positive influence on testis tissue (Figure 1A, B) and in the group that used ginger $(100 \mathrm{mg} / \mathrm{kg} /$ day), it also has a positive influence on testis (Figure 1D). In the group that used $(10 \mathrm{mg} / \mathrm{kg} /$ day) Lamotrigine the destructive effects of the mentioned drug on testis tissue resulted in destruction of germinal sexual cells, primary spermatozoids and destruction of parenchyma tissue of the testis (Figure 1C). In the group that simultaneously used Lamotrigine and fresh onion juice, the positive influences of the onion resulted in the coordination of sexual germinal cells and presence of sperms in the lumen tubule of seminiferous (Figure 1F) and in the group that simultaneously used ginger and Lamotrigine the destructive effect of the drug on the testis tissue was decreased (Figure 1E), and in the group that simultaneously was fed with onion, ginger and Lamortigine the destructive effects of the mentioned drug on testis tissue was diminished (Figure 1G). According to the mentioned explanations and samples of the testis tissue it was realized that onion and ginger have positive influences on testis, while Lamotrigine has a destructive effect. Simultaneously using Lamotrigine and onion and ginger causes the improvement and correction in the destroyed tissue which is the result of only Lamotrigine (Figure 1C, G).

\section{Results of sexual behavior and sexuality}

The results of studying the sexual behaviors of rats in different groups (control, Lamotrigine, onion, ginger, onion and Lamotrigine, ginger and Lamotrigine, onion and ginger and Lamotrigine) were seen. Rats that were fed with onion presented a meaningful increase in comparison with the control group on ejection, erection, cup (mating behavior) in sexual behavior and sexuality. The group that received Lamotrigine showed the least ejection, erection, cup in sexual behavior and sexuality. The group that simultaneously was fed with Lamotrigine and onion in comparison with group that only received Lamotrigine and in comparison with control group had more ejection, erection, cup in sexuality and sexual behaviors. The group that used ginger presented meaningful increase in comparison with control group, in ejection, erection, cup in sexual behavior and sexuality. In the group that simultaneously received Lamotrigine and ginger in comparison with the group that only received Lamotrigine and in comparison with the control group had more ejection, erection, cup in sexuality and sexual behaviors. In the group that simultaneously received Lamotrigine and ginger and onion in comparison with the group that only received Lamotrigine and in comparison with the control group, had more ejection, erection, cup in sexuality and sexual behaviors. Considering the results, it was recognized that onion and ginger increases sexuality and sexual behaviors. Lamotrigine drug causes reduction in sexuality and sexual behavior. Simultaneous use of onion and Lamotrigine, ginger and lamotrigine improves the negative effects caused by Lamotrigine on sexual behavior in tested rats (Table 2 ).
Table 2. Results of sexual behavior and sexuality: Erection, Ejection and Cup in studied groups and their results

\begin{tabular}{|c|c|c|c|}
\hline Groups & Erection & Ejection & Cup \\
\hline Control g. &,,,,----+ &,,,,---++ & -,י,-,י,-י \\
\hline Onion g. &,,,,$+++++^{*}$ &,,,,+++- &,,,,$+++++^{*}$ \\
\hline Ginger $\mathrm{g}$. &,,,,$++++-*$ &,,,,++-- &,,,,$-+++++^{\star}$ \\
\hline Lamotrigine g. &,,,,+--- &,,,,---- & - \\
\hline Onion\&Lamotrigine g. &,,,,$+++--^{\star}$ &,,,,++-- &,,,,$-+++++^{\star}$ \\
\hline Ginger\&Lamotrigine g. &,,,,++-- &,,,,---++ &,,,,$--+++^{\star}$ \\
\hline $\begin{array}{l}\text { Onion\&Ginger\& } \\
\text { Lamotrigine g. }\end{array}$ &,,,$+++--^{\star}$ &,,,,--+++ &,,,,$-++++*$ \\
\hline
\end{tabular}

\section{Discussion}

Many studies have previously been carried out concerning the effects of anti-convulsion drugs in creating disorder in sexual hormones and sexuality. Sexual hormone alterations are among the side-effects of anti-convulsant drugs $(5,25,26)$. Moreover, the mentioned study showed the reduction level of free testosterone (dihydrotestostrone), Follicle stimulating hormone, luteinized hormone, attaching globulin increase to sexual hormones and level of Estradiol in the users of enzyme infusing drugs. It was realized that using Lamotrigine does not cause changes in hormone level and does not change the sexual function. This study advises the users of the valproate sodium to use Lamotrigine in generalized idiopathic convulsion in the case of disorder in sexual function $(27,28)$. The results of the study concerning the reduction of testosterone hormone is incompatible with our study, however the results of the study showed that hormone level in Lamotrigine group in proportion to the control group has been reduced meaningfully. There was change in sexual function. In a large study carried out on humans, the result showed that, in addition to testosterone reduction, Lamotrigine causes reduction in sexuality and the mentioned result is compatible with ours $(1,2)$. Lamotrigine is effective in sexual changes. In this study, use of oxcarbazepine is suggested instead of Carbamazepine, which is an enzyme infusing drug $(29,30)$. The results of this study concerning the influence of Lamotrigine in creating sexual changes are compatible with our results (31). Anti-convulsant drugs interfere with hormone attached metabolism and causes changes in human procreation. Moreover, these drugs change the hormone treatment of pregnancy prevention (32). Anti-convulsant drugs causes increase of SHBG in serum and this protein attaches to the Estradiol and free testosterone in the serum and deactivates these hormones in the serum. It is possible that even though the amount of these two hormones is fixed in the tests, sexual disorders are observed in these patients (33). Studies have shown that drugs such as valproate cause disorders in exudation of testatropin by causing disorder in GABA; this drug can cause sexual disorder by a direct effect on hormones of the testis (34). Because of sexual disorder while using the anti-convulsion drugs and also because of the presence of low androgens in users of these drugs, 
problems in sexual stimulation and sexual disorder is observed in these individuals (35). The morphology of testes and sexual hormones in female-male Wister rats after long-term treatment with Lamotrigine was studied. In the mentioned study, 65 rats were selected and ( $5 \mathrm{~kg} / \mathrm{mg}$ ) Lamotrigine was injected twice a day for 90 days to these rats through a stomach pipe and the results showed that in male rats there were no significant differences in the weight of the testes. The atrophy of testes in one control rat and in two rats that received Lamotrigine was observed. The amount of FSH and $\mathrm{LH}$ and testosterone in the Lamotrigine group in proportion to the control group did not have a meaningful difference. Moreover, in male rats there was no change in morphology of the testes or other tissues and the amount of testosterone in serum, $\mathrm{LH}, \mathrm{FSH}$ and progesterone remained unchanged. In one case, estrogen of the serum reduced significantly. As it could be observed in the mentioned study the weight of the testes and hormones after treatment with Lamotrigine, did not show significant difference (36).

The results show that: different behaviors depended on Androgen, other secondary sexual specifications do not depend on testosterone equally, and dosage of necessary testosterone for sexual behavior is less than amount necessary for maintaining the weight of the testes and spermatogenesis of the testes. In our study, the receiver of the lamotrigine was meaningfully less than the control group. In the onion-receiving group, the amount of testosterone levels was meaningfully higher than the lamotrigine group. In the lamotrigine and onion-receiving group, the amount of hormone was meaningfully higher than the lamortigine group. Nowadays, many studies analyze the specification of the antioxidants in onion and their role in fertility and increasing sexuality which some mentioned $(37,38)$. The studies on chemical composition of onion showed that it is full of antioxidants such as Selenium and $E, A$, Flavonoids and Glutathione $(11,37,39)$. Studies showed that $C, E$, and $B$ vitamins are useful in reducing the poisonous effects on tissue of the testes (39). Also onion juice is effective on the sexual hormones in rats $(1,2)$. Finally, the results show that using onion is effective in increasing testosterone hormone and fertility. The results of the mentioned study are compatible with our study. In our study, in the onion receiving group in proportion to the lamotrigine group there was a meaningful increase in amount of testosterone and testis tissue. Comparing the onion group with the control group showed that there is a meaningful increase in the amount of testosterone. In the group of rats which were fed with lamotrigine and onion, there was a meaningful reduction in amount of testosterone hormone and testis tissue in proportion to the control group, and comparing these groups with lamotrigine shows a meaningful increase in testis tissue and testosterone level. In our study the results regarding the sexuality and sexual behaviors in seven groups (control, lamotrigine, onion, ginger, onion and lamotrigine, ginger and lamotrigine, onion and ginger and lamotrigine group) showed that onion and ginger cause an increase in sexuality in proportion to the control group. On other hand, it was recognized that this group's lamotrigine causes reduction in sexuality and the simultaneous use of lamotrigine, onion and ginger causes positive effects of onion and ginger on sexuality. It causes improvement in sexual behavior in proportion to a group of rats that only used lamotrigine. The main pharmacological actions of ginger and compounds isolated therefrom include immunomodulatory, anti-tumorigenic, anti-inflammatory, antiapoptotic, anti-hyperglycemic, anti-lipidemic and anti-emetic actions. Ginger is a strong anti-oxidant substance and may either mitigate or prevent generation of free radicals. It is considered a safe herbal medicine with only few and insignificant adverse/side effects (40). Oxidants and antioxidants have attracted widespread interest in nutrition research, biology and medicine. It has become clear that constant generation of pro-oxidants, including oxygen free radicals, is an essential attribute of aerobic life (41). In some studies, the effects of antioxidants of ginger was confirmed $(42,43)$. An inclusive study showed that the effect of ginger on male procreation is as follows: in the mentioned study after treatment with ginger, the weight of testis and epididymis increased significantly, also the number of sperms was counted and their movements increased also. After treatment, testosterone increased and malonhydriodehyde was reduced (44). In another study, 25 Wistar rats were used, in order to study the influence of onion and ginger on spermatogenesis, and they was divided into 5 groups (four groups for study and one for control). The first and second group were fed with fresh fruit juice. The first group received $(100 \mathrm{mg} / \mathrm{kg}$ ) and second one received $(50 \mathrm{mg} /$ $\mathrm{kg}$ ). The third and fourth groups were fed with ginger powder. Thus, the third group received $(100 \mathrm{mg} / \mathrm{kg}$ ) and fourth group $(50 \mathrm{mg} / \mathrm{kg}$ ). Analyzing the results showed that the number and living capability and movement power of sperms in all groups increased meaningfully in comparison with the control group $(p<0.05)$. Number of sperms only in the first group had meaningful increase in comparison to the control group. However, in other groups there was no meaningful difference in comparison with the control group. In addition, the weight of testis tissue in all groups is the same in comparison to the control group.

\section{Conclusion}

These findings lead to the conclusion that onion (3 cc fresh juice for each rat) and ginger (100 mg/kg/day) significantly lowered the adverse effects of lamotrigine, and can have a beneficial effect on sexual behavior in male rat.

\section{Acknowledgements}

Many thanks for my colleagues in Women's Reproductive Health Research Center, Tabriz University of Medical Sciences, Tabriz, Iran.

\section{Conflict of Interest}

No conflict of interest was declared by the authors.

\section{References}

1. Khaki A, Fathiazad F, Nouri M, Khaki AA, Ozanci CC, GhafariNovin M, Hamadeh M. The effects of Ginger on spermatogenesis and sperm parameters of rat. Ir J of Repr Med 2009;7:7-12. 
2. Khaki A, Fathiazad F, Nouri M, Khaki AA, Khamenehi HJ, Hamadeh M. Evaluation of Androgenic Activity of Allium cepa on Spermatogenesis in Rat. Fol Morph 2009;68:45-51.

3. Mosher WD, Pratt WF. Fecundity and infertility in the United States: incidence and trends. J Fert Ste 1991;56:192-3.

4. Sekiwa Y, Kubota K, Kobayashi A. Isolation of novel glucosides related to gingerdiol from ginger and their antioxidative activities. J Agr Food Che 2000;48:373-7. [CrossRef]

5. Kamtchouing P, Mbongue Fandio GY, Dimo T, Jatsa HB. Evaluation of angrogenic activity of Zingiber officinale and pentadiplandra brazzeana in male rats. Asi J And 2002;4:299-301.

6. Augusti KT. Therapeutic values of onion and garlic. Indi J Exp Bio 1996;34:634-40

7. Lee SU, Lee JH, Choi SH, Lee JS, Ohnisi-Kameyama M, Kozukue N, et al. Flavonoid content in fresh, home-processed, and light-exposed onions and in dehydrated commercial onion products. J. Agr. Food Chem 2008;24:8541-8. [CrossRef]

8. Kumari K, Mathew BC, Augusti KT. Antidiabetic and hypolipidemic effects of SMCS isolated from Allium Cepa Linn. Ind J Bioch Bio 1990;32:49.

9. Markham KR. Techniques of flavonoid identification. Academic Press 1982, London.

10. Rajeev K, Gagan G, Narmada P. Drug Therapy for Idiopathic Male Infertility: Rationale Versus Evidence. J of Uro 2006;176:1307-12. [CrossRef]

11. Yang HS, Han DK, Kirn JR, Sim JC. Effects of alpha-tocopherol on cadmium-induced toxicity in rat testis and spermatogenesis. J Kor Med Sci 2006;21:51-445. [CrossRef]

12. Zancan KC, Marques MO, Petenate AJ, Meireles MA. Extraction of ginger (Zingiber officinale Roscoe) oleoresin with $\mathrm{CO} 2$ and cosolvents: a study of the antioxidant action of the extracts. J Sup Flu 2002;24:57-76. [CrossRef]

13. Hawley W, Grissom E, Keskitalo L, Hastings T, Dohanich G. Sexual motivation and anxiety-like behaviors of male rats after exposure to a truma followed by situational reminders. Phy. and beh 2011;102:181-7.

14. Vasilenko SA, Ram N, Lefkowitz ES. Body image and first sexual intercourse in late adob scence. J of Adlole 2010;34:327-35. [CrossRef]

15. Clayton $\mathrm{AH}$. The pathophysiology of hypoactive sexual desire disorder in women. Gyneco 2010;110:7-11.

16. Oviedo-Joekes E, Marchand K, Guh D, Marsh DC, Brissette S, Krausz $M$, et al. History of reported sexual or physical abuse among long-term heroin users and their response to substitution treatment. Add Beh 2011;36:55-60. [CrossRef]

17. Benotsch EG, Koester S, Luckman D, Martin AM, Cejka A. Nonmedical use of prescription drugs and sexual risck behavior in young adults. Add Beh 2011;36:152-5. [CrossRef]

18. Patrick ME, Maggs JL. Profiles of motirations for alchol use and sexual behavior among first-year university students. J of Adole 2010;33:755-65. [CrossRef]

19. Boris B, Gorzalka IV. The effect of vitamin B6 on sexual behavior in the rat,possibly through serotonergic mechasisms. Nut Res 1994;14:279-85. [CrossRef]

20. Yousef Ml. Protective effect of ascorbic acid to enhance reproductive performance of male rabbits treated with stannous chloride. Toxi 2005;207:81-9. [CrossRef]

21. W.H.O., W.H.O. monographs on selected medicinal plants. Malta 1999;1:86-277.

22. Huang HF, Linsenmeyer TA, Li MT, Giglio W, Anesetti R, von Hagen J, et al. Acute effects of spinal cord injury on the pituitary-testicular hormone axis and Sertoli cell functions: a time course study. J And 1995;16:14857.

23. Røste LS, Taubøll E, Mørkrid L, Bjørnenak T, Saetre ER, Mørland T, et al. Antiepileptic drugs alter reproductive endocrine hormones in men with epilepsy, Euro J of Neurol 2005;2:24-118.
24. Feng $\mathrm{R}, \mathrm{He} \mathrm{W}$, Ochi $\mathrm{H}$. A new murine oxidative stress model associated with Senescence. Mec Age Dev 2001;122:547-59. [CrossRef]

25. Chen CY, Liu TZ, Liu YW, Tseng WC, Liu RH, Lu FJ, et al, 6-Shogaol (Alkanone from Ginger) Induces Apoptotic Cell Death of Human Hepatoma p53 Mutant Mahlavu Subline via an Oxidative StressMediated Caspase- Dependent Mechanism. J Agr Food Chem 2007;55:54-948. [CrossRef]

26. Liew SH, Meachem SJ, Hedger MP. A stereological Analysis of the Response of Spermatogenesis to an Acute Inflamatory Episode in Adult Rat. J And 2007;28:176-85.

27. Chen SS, Shen MR, Chen TJ, Lai SL. Effects of antiepileptic drugs on sperm motility of normal controls and epileptic patients with longterm therapy. Epile 1992;33:149-53. [CrossRef]

28. Fielder TJ, Peacock NR, McGivern RF, Swerdloff RS, Bhasin S. Testosteronn dose-dependency of sexual ans nonsevual behaviors in the gonadotropinrelesing kormone antagonist- treated male rat. J of And 1989:10:167-73.

29. Chairgulprasert V., Prasertsongskun S., Wichaporn W., Chemical constituents of the essential oil and antibacterial activity of Zingiber wrayi var. halabala Songklanakarin. J Sci Tech 2005;27:8-813.

30. Røste LS, Taubøll E, Isojarvi Jl, Berner A, Berg KA, Pakarinen AJ, et al. Gonadal morphology and sex hormones in male and female Wistar rats after long-term lamotrigine treatment. Seiz 2003;12:621-7. [CrossRef]

31. Morrell M.J., Isojarvi J., Taylor A.E., Dam M., Ayala R., Gomez G., Higher androgens and weight gain with valproate compared with lamotrigine for epilepsy. Epi Res Pak J Biol Sci 2008;11:9-1683.

32. Penovich PE. The effects of epilepsy and its treatment on sexual and reproductive function. Min Epi Gro Sai Paul 2008;17:30-127.

33. Isojarvi J. Disorders of reproduction in patients with epilepsy: Antiepileptic drug related mechanisms. Sei 2008;17:111-9. [CrossRef]

34. Sveberg Røste L, Taubøll E, Isojärvi Jl, Pakarinen AJ, Huhtaniemi IT, Knip $M$, et al. Effects of chronic valproate treatment on reproductive endocrine hormones in female and male Wistar rats. Repro Tox 2002;16:767-73. [CrossRef]

35. Luef GJ. Epilepsy and Sexuality. Seiz 2008;17:12730. [CrossRef]

36. Bone B, Janszky J. Epilepsy and male sexual dysfunction: etiology, diagnosis and therapy. Epi Beh 2006;1:8-22.

37. Amin A., Hamza A.A., Effects of Roselle and Ginger on cisplatininduced reproductive toxicity in rats. Asi J And 2006;8:12-607.

38. Basta-Kaim A, Budziszewska B, Leśkiewicz M, Kubera M, Jagła G, Nowak W, et al, Effects of new antiepileptic drugs and progabide on the mitogen-induced proliferative activity of mouse splenocytes. Pha Rep 2008;60:925-32.

39. Yang CY, Chao PD, Hou YC, Tsai SY, Wen KC, Hsiu SL. Marked decrease of cyclosporine bioavailability caused by coadministration of ginkgo and onion in rats. J Foo \& Chemi Toxi 2006;44:8-1572.

40. Ali BH, Blunden G, Tanira MO, Nemmar A. Some phytochemical, pharmacological and toxicological properties of ginger (Zingiber officinale Roscoe): a review of recent research. Food Chem Tox 2008;46:409-20. [CrossRef]

41. Sies H. Oxidants and antioxidants. In: Oxidative Stress. Academic Press London 1991;15-22.

42. Singh G, Kapoor IP, Singh P, de Heluani CS, de Lampasona MP, Catalan CA. Chemistry, antioxidant and antimicrobial investigations on essential oil and oleoresins of Zingiber officinale. Food \& Chemi Tox 2008;46:3295-302. [CrossRef]

43. Stoilova L, Krastanov A, Stoyanova A, Denev P, Gargova S. Antioxidant activity of a ginger extract (Zingiber officinale). Food Chemi 2007;102:764-70. [CrossRef]

44. Morakinyo A, Adeniyi O, Arikawe A. Effects of Zingiber Officinale on Reproductive Functions in the Male Rat. Afri J of Bio Res 2008;11:329-34. 